\title{
Patterns of intergenerational support in grandparent-grandchild and parent-child relationships in Germany
}

\author{
ANDREAS HOFF*
}

\begin{abstract}
The paper focuses on intergenerational support relations between grandparents and their grandchildren in Germany, and how they have changed from I996 to 2002. The paper begins with a brief review of the literature on functional aspects of the grandparent-grandchild relationship, after which the research hypotheses about intergenerational support in the relationship are elaborated. Following a description of the data source, the German Ageing Survey, and its samples and measures, the evidence on the patterns of grandparents' provision and receipt of intergenerational support to and from their grandchildren are presented and compared with parent-child support patterns. The analysis also considers variations by age groups and birth cohorts and changes over time. The main empirical finding is that there was a greater likelihood of financial transfers to grandchildren in 2002 than six years earlier. Nevertheless, the grandparents' relationships with their grandchildren remained imbalanced or asymmetrical, at the older generation's expense. It was found that financial and instrumental support patterns between grandparents and grandchildren were best explained using an 'intergenerational stake' hypothesis rather than one of 'intergenerational solidarity'; the latter is more consistent with parent-child support patterns.
\end{abstract}

$\boldsymbol{K E Y} \boldsymbol{W O R D S}$ - grandparents, intergenerational relations, intergenerational solidarity, intergenerational stake, informal support, Germany.

\section{Introduction}

Despite popular belief, the widespread experience of grandparenthood is a recent phenomenon. In the past, intergenerational relations across three generations were very rare and usually of short duration (Hareven 200I; Lauterbach I995a). Today, family networks with four generations have become relatively common, and three-generation family networks are the norm (Harper 2005; Hoff 2006a). Grandparenthood has become

* Oxford Institute of Ageing, University of Oxford. 


\section{Andreas Hoff}

inseparably linked to old age and the role is seen as a normal stage of the family cycle (Hoff and Tesch-Römer 2007). Most people not only become grandmothers or grandfathers but also see their grandchildren grow up, many to the point that they have begun a family of their own. Quite a few live to see their great-grandchildren growing up. Bengtson (200I) suggested that grandparents will play an increasingly important role in multigenerational families. The combined effects of rising life expectancy (more years spent with grandchildren) and falling fertility (fewer grandchildren) may even have unexpected side effects, such as fit and wealthy grandparents competing for the attention of fewer grandchildren (Uhlenberg 2005).

In Germany, only recently has a sociological research interest in grandparenthood been seen, which is astonishing given that never before have there been so many grandparents and grandchildren. Lauterbach (I995a) estimated that in the mid-I950s, only I3 per cent of Io-year-old children had all four grandparents alive - compared with 36 per cent in the mid-iggos. By the new millennium, about go per cent of German children had at least one grandmother and 70 per cent had a grandfather (Lauterbach 2002). According to the German Ageing Survey of 1996, nearly two-thirds of 55-69 year-olds had grandchildren, and more than 80 per cent of 70-85 year-olds (Kohli et al. 2000). Moreover, contemporary grandparent-grandchild relationships last much longer than formerly. By the mid-I99os, German grandparents and grandchildren had known each other for an average of 20 years (Lauterbach $1995 b$; Lauterbach and Klein 1997).

One objective of this paper is to examine change and continuity in intergenerational-support relations between grandparents and grandchildren in Germany between I996 and 2002. The paper has several sections, the first being a theoretical discussion. Two frameworks that were originally developed to explain intergenerational relationships between contiguous generations have been applied to the grandparent-grandchild relationship: the concept of 'intergenerational solidarity' (Bengtson and Roberts 199I), and the 'intergenerational stake hypothesis' (Giarrusso, Stallings and Bengtson 1995). Research hypotheses have been deduced from both concepts and complemented by age-related hypotheses. After the theoretical sections, the data for the analysis from the German Ageing Survey are described. The findings sections begin with an account of the mutual support patterns between grandparents and grandchildren, that is the functional aspects of their relationships. These are compared with those of parent-child relationships, and then the impact of grandparents' age on the relationship and specific aspects of the support pattern are explored. 


\section{Grandparents as family supporters}

If the growing number of grandparents in Germany stimulated little sociological research interest until the mid-I9gos, the functional dimensions of grandparent-grandchild relationships raised even less. Grandparents were first addressed as support providers in practice-oriented publications in social work and family therapy. As in the United States, the earliest publications emphasised the important role that grandparents play in managing family crises, such as the divorce, separation or unemployment of their children (Fabian I994; Fthenakis I998). There were similar early studies in educational sociology that focused on child-care provision by grandparents at times of crisis (Sommer-Himmel 200I). A study of the informal-support mobilisation strategies of lone mothers, who are arguably more in need of grandparental support than two-parent families, found that on occasion German grandparents played a vital role in providing emergency child-care (Hoff 2006 b).

The notion of 'intergenerational learning' has motivated other studies of the functional aspects of the grandparent-grandchild relationship (e.g. Krappmann 1997; Lange and Lauterbach 1998; Lüscher and Liegle 2003). While Krappmann (1997) emphasised the role that grandparents played in the socialisation of their grandchildren, Lüscher and Liegle (2003) stressed the mutuality of intergenerational learning in the grandparentgrandchild relationship. During the I99os, several researchers with an interest in intergenerational relations began explicitly to examine the relationship between grandparents and grandchildren (e.g. Lange and Lauterbach I997, I998; Lauterbach I995b, 2002; Marbach I994; Wilk I993).

In contrast to the concerns of German researchers, the functional aspects of the grandparent-grandchild relationship have been a recurring theme in North American family sociology for over 6o years (Szinovacz I998). One of the first studies of grandparenthood stressed the supporting role of grandmothers as 'rescuers' of families (von Hentig I946); this theme re-emerged during the I970s and I980s in the wake of the rising numbers of divorces, 'out-of-wedlock' births, and lone mothers (e.g. Cherlin and Furstenberg I986; Kivett I985). More recently, the supportive function of grandparents has remained high on the US research agenda (see Baydar and Brooks-Gunn 1998; Silverstein, Giarrusso and Bengtson I998). Bass and Caro (I996) estimated that American grandparents provided child-care services worth $\$ 17-29$ billion each year.

Recent American and British publications on functional aspects of the grandparent-grandchild relationship have been concerned with the potentially harmful effects of family change. Cooney and Smith (I996) 


\section{Andreas Hoff}

examined the impact of parental divorce on functional solidarity between grandparents and their adult grandchildren - but did not find any association. British researchers have studied grandparenting in divorced families (Ferguson 2004), in support of lone parents (Harper et al. 2004), and in reconstituted families (Dimmock et al. 2004). A shared conclusion was that the maternal grandmother line attempts to preserve frequent contacts with grandchildren, whereas the paternal grandparent line maintains only limited contact. A French study produced similar findings and emphasised the implication that there was a higher propensity for support from the maternal than the paternal line (Gauthier 2002). Custodial grandparenting is another keenly debated issue. According to Harper (2005), some 3.7 million grandparents currently help in raising 3.9 million children in the United States. Silverstein (2006) noted that research has for long tended to depict intergenerational transfers by grandparents as an expression of altruism and self-sacrifice, especially given that grandparents who assume parenting roles often do so at great cost to their material, physical and mental wellbeing (Minkler et al. 2000). On the other hand, Pruchno (i999) emphasised that many custodial grandmothers found the role rewarding.

The introduction in the United States during the I99os of large, population-based surveys with questions about intergenerational support stimulated the research interest in transfers between grandparents and grandchildren (Kronebusch and Schlesinger I994). Not only did this provide considerable improvements in the data resources and methodologies for studying supportive relations between grandparents and grandchildren, but several theoretical concepts that were originally developed to explain supportive behaviour between contiguous generations were applied to the grandparent-grandchild relationship. They have provided the theoretical framework for the present analysis.

\section{Hypothesising intergenerational support}

\section{The intergenerational solidarity hypothesis}

Vern Bengtson developed the intergenerational solidarity construct with the parent-child relationship in mind (for the precursors and elaboration of the solidarity model, see Bengtson 1975; Bengtson, Olander and Haddad 1976; Bengtson and Schrader 1982). The concept refers to the patterns of solidarity between parents and their adult children at different stages of the lifecourse that promote intergenerational cohesion. Bengtson and his colleagues recognised the complex nature of the intergenerational solidarity construct, though later it proved even more 
multi-dimensional than first thought. The originally proposed three dimensions of normative, functional and structural solidarity were criticised because they failed to take into account the associations among the dimensions ( $c f$. Atkinson, Kivett and Campbell I986; Roberts and Bengtson I990). Bengtson and Roberts (I99I) then augmented the construct and posited another three dimensions - associational, affectional and consensual solidarity. The intergenerational solidarity construct has subsequently become very influential, and has inspired numerous empirical studies worldwide (e.g. Attias-Donfut 2003; Bawin-Legros and Stassen 2002; Kohli et al. 2000; Hoff 2007).

Most relevant for the research reported in this paper is the functional solidarity dimension. It refers to the extent of resource sharing and (mutual) support provision of various kinds, including financial, material, instrumental, emotional and cognitive support. It takes into account both objective (e.g. frequency of support) and subjective aspects (e.g. perception of support received). Silverstein, Giarrusso and Bengtson (I998) later applied the model to grandparent-grandchild relations. They drew attention to the various types of grandparental support to young grandchildren, including child-care, custodial care, and emotional, financial and instrumental support. They found that, by contrast, grandparents received expressive and instrumental support from adult grandchildren. The first research hypothesis on functional solidarity to be examined refers to this mutuality of support between grandparents and grandchildren:

Functional solidarity hypothesis: Mutuality of resource sharing and support provision is a necessary precondition of functional solidarity. If 'intergenerational solidarity' applies to grandparent-grandchild relationships, there must be 'give and take' of support between the two generations.

\section{The intergenerational stake hypothesis}

While the intergenerational solidarity construct explains the mutuality of supportive relations between older and younger people, it does not indicate how much they provide for one another. The intergenerational stake hypothesis elucidates this issue (Giarrusso, Stallings and Bengtson I995). It reflects the empirical finding that older parents consistently report higher levels of closeness and consensus in their relationships with their (adult) children than do their children of their parents; in other words, the two generations have different 'stakes' in the mutual relationship. Whereas parents tend to be more concerned with family continuity and preserving close relationships within the family, children tend to be most concerned with defending their individuality and retaining their autonomy and independence. As a consequence, parents tend to overstate 


\section{Andreas Hoff}

intergenerational solidarity and to underestimate intergenerational conflict. In contrast, children tend to show less commitment to intergenerational solidarity and to overstate conflicts.

Several studies have confirmed the intergenerational stake hypothesis (e.g. Caldwell, Antonucci and Jackson I998; Crosnoe and Elder Jr 2002; Harwood 200I). Giarrusso et al. (200I), however, painted a more equivocal picture of the validity of the intergenerational stake hypothesis. They found that the intergenerational stake phenomenon is particularly prevalent in Euro-American grandparents' relationships with granddaughters, but far less so in their relationship to grandsons. Moreover, they pointed to ethnic variations. Mexican grandsons showed more affection for their grandfathers than was reciprocated. Given the ethnically homogeneous sample for the analyses reported here, the intergenerational stake hypothesis was seen as highly relevant:

Intergenerational stake hypothesis: If the 'intergenerational stake hypothesis' applies to the functional relationship between grandparents and grandchildren, the proportion of grandparents providing support to their grandchildren will be higher than that of grandchildren providing help to their grandparents.

\section{Age differentiation and changing needs hypotheses}

The research evidence on the effect of grandparents' and grandchildren's ages on their relationships suggests that an alternative hypothesis explains variations in the levels of both the provision and the receipt of intergenerational support (e.g. Hodgson 1998; Roberto and Stroes 1995; Silverstein and Long 1998). It has been shown that relationships between adult grandchildren and their grandparents differ from those between young grandchildren and their grandparents. When grandchildren are young, grandparents provide support (typically child-care), although one can argue that such support is for the parents as well as the grandchild(ren). Grandparents tend to live closer to younger than to older grandchildren and to have more frequent contact with them (Silverstein and Marenco 200I). By the time that grandchildren reach adulthood, their grandparents tend to need more support as a result of frailness and multimorbidity, while grandchildren have the capacity to give more support than when they were young. As a consequence, the relationship becomes more oriented towards the support of the grandparent (Ross et al. 2002). Langer (I990) found that the majority of relationships between adult grandchildren and their grandparents were imbalanced at the grandchildren's expense, and remarkably reported that the grandparents in her sample 
perceived the relationship to be reciprocal when they received more than they gave. On the other hand, grandparents continued to provide support - most often financial support (Silverstein and Marenco 200I).

This age-related argument effectively contradicts the intergenerational stake hypothesis for support relations between adult grandchildren and their grandparents and points instead to the 'support bank' hypothesis (Antonucci 1990). This was developed with reference to the parent-child relationship and proposed that investments in children at early stages of their lives are withdrawn later in life when parents require support. This reasoning leads to the third and fourth hypotheses:

Age differentiation hypothesis: Mutual support patterns of financial and instrumental support between grandparents and grandchildren vary with age.

Changing needs and capacity hypothesis: The intergenerational stake hypothesis does not apply to support relations between adult grandchildren and their very old grandparents ('very old' being defined as aged 80 or more years). In these relationships, support patterns are needs-based, i.e. grandchildren provide more support than when younger, because of their greater capacity to provide and the greater needs of the grandparents.

\section{Design and methodology}

The analysis drew on data from the first and second wave of the German Ageing Survey (Alterssurvey) carried out in 1996 and 2002. ${ }^{1}$ The survey focused on individuals in the 'second half of life' (zweite Lebenshälfte), i.e. the middleaged and older population of Germany (Hoff et al. 2003). It was established to create a database that would enable researchers, policy makers and the interested public to gain a comprehensive understanding of the societal implications of population ageing. Data were collected on employment history, income, property and assets, housing, intergenerational relations and social support, productive activities, social networks and integration, wellbeing and individual health (for the instruments used see Dittmann-Kohli et al. I997; Tesch-Römer et al. 2002).

The first wave of the survey in 1996 interviewed $4,83^{8}$ people aged $40-85$ years living in private households. The initial ambition to collect longitudinal data was realised at the second wave in 2002, when I,524 of the original participants (then aged $46-9 \mathrm{I}$ years) were re-interviewed (Figure I). The relatively small re-interview sample was because only 2,873 of the baseline sample agreed to take part in the second wave, combined with the usual attrition in panel studies of older people through mortality, 


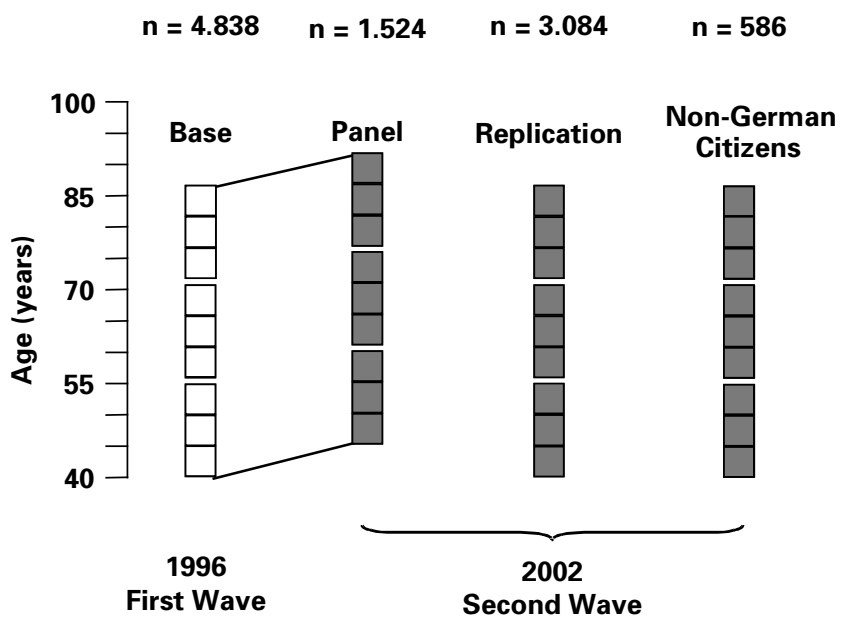

Figure I. The samples of the German Ageing Survey I996 and 2002.

in particular in the oldest age groups (for an analysis of the non-response rates see Engstler and Wurm 2006). To enable cross-cohort analyses, a replication sample of 3,084 individuals aged 40-85 years was created in 2002, repeating the sampling strategy used for the baseline sample of 1996 . A third, non-German, sample was an innovation in German gerontology. For the first time, a nationwide sample (586) of older non-Germans was interviewed (viz. those without a German passport). The sample provided information about the specific circumstances of the gastarbeiter (guest worker) population that had reached retirement age (which is ageing even more rapidly than the German population). ${ }^{2}$ Given the age range (40-85 years) of the German Ageing Survey sample, not surprisingly a mere five per cent indicated that they had living grandparents, but 44 per cent reported having grandchildren (Hoff 2006a). As a consequence of the data structure, in this article grandparent-grandchild relationships are examined only from the grandparents' perspective, an obvious limitation.

\section{Intergenerational support across one and two generations}

The concern that population ageing would overburden familial support networks is prominent in the German public debate about the implications of population ageing, which frequently pictures older people as needy and as passive recipients of help. In contradiction to this anachronistic but persistent stereotype, the majority of older people support the younger generations in their families. Several publications based on the first wave of the German Ageing Survey showed that the older generations 
give far more support than they receive (e.g. Kohli et al. 2000; Künemund, Motel-Klingebiel and Kohli 2005; Motel-Klingebiel 2000; Szydlik 2000). But whereas inter-personal transfers between parents and children have been relatively well charted, those between grandparents and grandchildren have received little attention.

To measure the provision and receipt of informal financial transfers, the interviewees were asked the following questions (in my translation from the German): 'Many people make gifts of money or gifts in kind, or support others financially, for example, parents, children, grandchildren, other relatives, friends or acquaintances. How does this apply to you? During the previous 12 months, did you give money or large presents to anyone, or did you support anyone financially on a regular basis? [And the other way round]: Did you receive gifts of money or large gifts in kind or did anyone support you financially regularly during the previous I2 months?' The present analysis is limited to $62-85$-year-olds, i.e. the birth cohorts in which the majority had already become grandparents.

Although the questions allowed the provision or receipt of regular financial support to be reported, such exchanges were rare and instead one-off gifts were the rule. Only six per cent of the grandparents aged 62-85 years in 2002 who supported others financially at all gave money regularly to their grandchildren, but 17.5 per cent did so to their children. In contrast, one-off financial gifts to grandchildren were common and by far the most frequent type of private financial transfer. Of the grandparents in this age group who had provided financial support, go per cent had given money to their grandchildren, compared with 83 per cent who had made such gifts to their children. Nearly one-quarter made large gifts to their grandchildren - one-fifth did the same for their children. These differentials applied to men and women and to both East Germans and West Germans. Some provided several types of financial transfers, while others reported just one transaction. A limitation of the data is, however, that there is no information on the frequency or amounts of the transfers during the previous year.

Instrumental support was measured similarly by asking for details of the help provided by individuals living outside the interviewee's household. The question was: 'Apart from caring activities already mentioned and other activities that you carry out as part of your job, during the previous I2 months did you help anyone who does not live in your household with the chores, e.g. with cleaning, small repairs, or shopping? And please tell me about the converse: during the previous I2 months, did anyone who does not live in your household help you with chores, e.g. cleaning, small repairs, or shopping?' Unlike the questions on financial transfers, the survey did not ask about different types of instrumental support. 


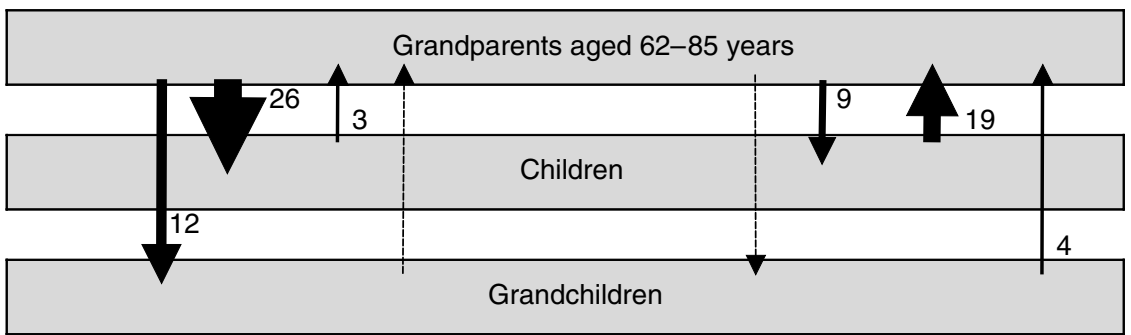

2002

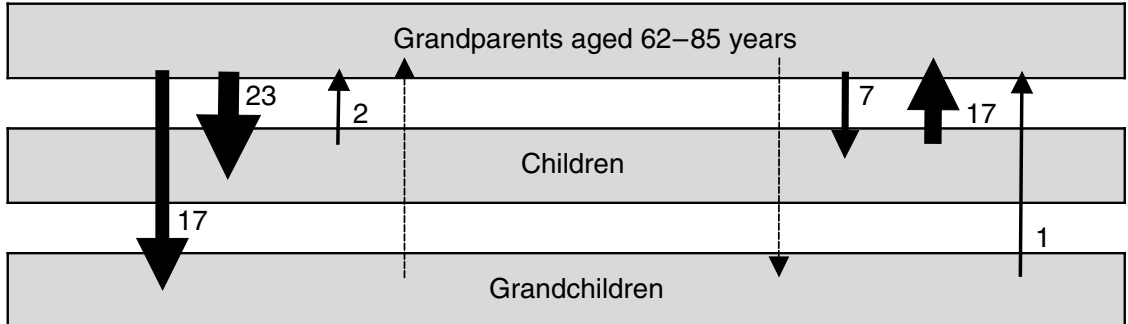

Source: German Ageing Survey. For 1996, all respondents in baseline sample aged 62-85 years who were grandparents $(n=I, 586)$; weighted data. For 2002, all respondents in replication sample aged $62-85$ years who were grandparents $(n=I, 2 I I)$; weighted data. For further details, see text.

Notes: The annotated numbers are rounded percentages. A dashed line indicates provision or receipt of financial transfers or instrumental assistance by less than one per cent of the grandparents aged $62-85$ years.

Figure 2. Intergenerational support patterns in Germany, I996 and 2002.

Figure 2 summarises the patterns of mutual financial and instrumental support between grandparents and both their children and grandchildren (but not between the two younger generations) in 1996 and 2002. The strength of the arrows on Figure 2 indicates the proportion of the group that provided support during the two years. ${ }^{3}$ The upper part of the Figure depicts a pattern of support between parents and their adult children that was well established during the mid-iggos. Older Germans supported their children mainly by means of financial transfers, and their children reciprocated through instrumental assistance. They also made financial contributions to their grandchildren, but children were far more likely to be recipients of financial support than grandchildren. More than onequarter $(26 \%)$ provided financial support to their children at least once during the previous year, compared with 12 per cent who did the same for their grandchildren. 
Figure 2 also demonstrates that the mutual support was asymmetrical. Although the younger generations returned financial transfers with instrumental assistance, they were far less likely to do so than to receive support: I9 per cent of children and only four per cent of grandchildren had helped the grandparents at least once during the previous year, consistent with the intergenerational stake hypothesis. The mutuality of transfers in the parent-child relationship supported the functional solidarity hypothesis, but too few grandparents reported instrumental assistance from their grandchildren to confirm the applicability of the functional solidarity hypothesis. The counter-flows (financial transfers from the younger generations to the grandparents and instrumental help from the grandparents to the younger generations) were insignificant (the thinnest lines on the figure indicate a prevalence of less than one per cent).

Broadly, the patterns described for 1996 persisted in 2002. The lower panel of Figure 2 shows that older Germans were still more likely to support their children financially $(23 \%)$ than to receive instrumental support ( $17 \%)$. Moreover, a greater proportion transferred financial assistance to their children than to their grandchildren. There had, however, been a significant shift in the proportion that provided financial transfers over the previous year - away from children $(-3 \%)$ and towards grandchildren $(+5 \%)$. Support given to grandchildren of course also helps their parents, but nevertheless this was a remarkable change in just a few years.

\section{The impact of grandparents' age on intergenerational support}

A limitation of the German Ageing Survey is that it did not collect grandchildren's ages. Table I distinguishes four age groups of grandparents $(62-67,68-73,74-79$ and 80-85 years), born respectively in 1929-34, I923-28, I9I -22 and I9II-I6 (I996 sample) and in 1935-40, I929-34, I923-28 and 1917-22 (2002 sample). In I996, financial transfers to grandchildren were most common by the oldest age group (I7 per cent reported such gifts), while among those aged 62-67 years only one-half of that percentage made similar transfers. In comparison, there was little variation across the four age groups in the proportions that made financial transfers to children, although the percentage of grandparents that gave to children was significantly higher than the percentage that gave to grandchildren. The age distribution of those who gave financial support to their children was strikingly different from the age distribution of those who gave to grandchildren. Financial transfers to children were most likely by those in the two youngest age groups, while such support to grandchildren was clearly more common from the older age cohorts. It is unclear to what 
T A B L E I. Intergenerational support patterns by age group of grandparents, Ig96 and 2002, Germany

\begin{tabular}{|c|c|c|c|c|c|c|c|c|}
\hline & \multicolumn{4}{|c|}{ Age group (years) I996 } & \multicolumn{4}{|c|}{ Age group (years) 2002} \\
\hline & $62-67$ & $68-73$ & $74-79$ & $80-85$ & $62-67$ & $68-73$ & $74^{-79}$ & $80-85$ \\
\hline From grandparents: & \multicolumn{8}{|c|}{$P e r c e n t a g e s$} \\
\hline \multicolumn{9}{|l|}{ Financial transfers: } \\
\hline To children & 27 & 29 & $2 \mathrm{I}$ & 23 & 28 & 23 & 20 & $\mathrm{I} 5$ \\
\hline To grandchildren & 8 & $\mathrm{I} 4$ & I2 & I7 & I4 & $2 \mathrm{I}$ & 20 & I5 \\
\hline \multicolumn{9}{|l|}{ Instrumental support: } \\
\hline To children & I2 & IO & 5 & 4 & 8 & 8 & 5 & 5 \\
\hline To grandchildren & $<_{\mathrm{I}}$ & $<_{\mathrm{I}}$ & $<\mathrm{I}$ & o & $<\mathrm{I}$ & $<\mathrm{I}$ & o & o \\
\hline \multicolumn{9}{|l|}{ To grandparents: } \\
\hline \multicolumn{9}{|l|}{ Financial transfers: } \\
\hline From children & I & 4 & 2 & 4 & I & 4 & 2 & 2 \\
\hline From grandchildren & o & $<\mathrm{I}$ & $<_{\mathrm{I}}$ & $\mathrm{o}$ & $<\mathrm{I}$ & $<\mathrm{I}$ & o & o \\
\hline \multicolumn{9}{|l|}{ Instrumental support: } \\
\hline From children & I4 & 20 & 22 & 29 & I3 & I3 & 20 & $3^{0}$ \\
\hline From grandchildren & $<\mathrm{I}$ & 4 & 7 & 7 & $<\mathrm{I}$ & 2 & 3 & 2 \\
\hline \multicolumn{9}{|l|}{ Differentials: } \\
\hline \multicolumn{9}{|l|}{ Financial transfers: } \\
\hline To/from children & 26 & 25 & I9 & I9 & 27 & I9 & I8 & I3 \\
\hline To/from grandchildren & 8 & I3 & II & I7 & I3 & 20 & 20 & I5 \\
\hline \multicolumn{9}{|l|}{ Instrumental support: } \\
\hline To/from children & -2 & - IO & -17 & -25 & -5 & -5 & $-\mathrm{I} 5$ & -25 \\
\hline To/from grandchildren & o & -3 & -6 & -7 & $\mathrm{o}$ & $-\mathrm{I}$ & -3 & -2 \\
\hline
\end{tabular}

Source: German Ageing Survey, I996: all respondents aged 62-85 years who were grandparents in baseline sample $(\mathrm{N}=1,586)$, weighted data. 2002: all respondents aged 62-85 years who were grandparents in replication sample $(\mathrm{N}=\mathrm{I}, 2 \mathrm{II})$; weighted data.

extent this is an age or a cohort effect (or both), but age-differentiation is clearly confirmed.

The receipt of instrumental assistance from children was by contrast largely age-dependent and needs-based, confirming the fourth hypothesis. Instrumental support was most likely to be given to $80-85$ year-olds. The likelihood of instrumental help from children exceeded that of financial transfers in the other direction. Evidence for the applicability of both the 'functional solidarity' and the 'needs and capacity' hypotheses to the parent-child relationship was found, but the 'intergenerational stake' hypothesis was not supported for the oldest age-group's relationships with their children, who were more likely to provide instrumental assistance than to receive financial help. The grandparent-grandchild relationship was imbalanced at the grandparents' expense. Grandparents were far more likely to give financial support to their grandchildren than to receive instrumental assistance from them. In fact, they received hardly any instrumental assistance from their grandchildren. This finding supports the 
validity and dominant influence of the 'intergenerational stake' hypothesis in grandparent-grandchild relationships.

It has been noted that a greater percentage of financial transfers went to grandchildren in 2002 than in I996 (Figure 2). An analysis by age groups revealed that it was the three younger age groups that were responsible for the higher likelihood, while the gifts made by the oldest age group hardly changed. On the other hand, 80-85-year-olds were mainly responsible for the eight per cent decrease since 1996 in financial transfers to children. The remarkable consequence was that the same percentage of children and grandchildren ( $15 \%$ ) of the oldest cohort received financial support in 2002. How are these changes to be interpreted? They may signal a period effect, by which changes in the social environment manifested in changed attitudes to support. One may speculate that the increasingly intense public debate on pension reform in Germany since the late ig9os has resulted in greater financial caution among the oldest age groups, who arguably are the most vulnerable to changes in pension, investment and social security income, but the possibility of a cohort effect must be considered. Three of the four age groups examined in 1996 were still in the 2002 sample, specifically those born in $1917^{-22}, 1923^{-28}$ and $1929-34$. If a particular support pattern was rooted in the life experience of a specific birth cohort - let's say, those born 1929-34-it should be recognisable among those aged 62-67 years in 1996 and those aged 68-73 years in 2002. This was not, however, the case. Whereas only eight per cent of this cohort reported financial transfers to grandchildren in I996, more than one-fifth made such gifts in 2002. Similar differences can be found when following the other two 1996 cohorts in 2002. Hence, cohort effects do not appear to be the main explanatory force. Age-related effects, possibly confounded by period effects, were more likely to account for the changed pattern of transfers.

\section{The occurrence of support exchange in intergenerational relations}

The presented findings give the impression that intergenerational support followed an exchange pattern, if slightly imbalanced at the expense of the older generation, but was this really the case? The results actually show that the older generation provided mainly financial support to both their children and grandchildren, and that their children assisted the parents with instrumental help. A cross-cohort analysis in 1996 and 2002 enabled a more authoritative test of whether intergenerational support between grandparents and grandchildren followed an exchange pattern. For this analysis, each logical combination of financial (A, yes or no) or 
instrumental (B) support provision by grandparents $(\mathrm{C})$ or grandchildren (D) was assigned a category value, thereby creating $2^{4}$ or 16 combinations. They ranged from a comprehensive pattern of transfers, with both financial and instrumental support being provided by both grandparents and grandchildren, to no support transfers at all.

The vast majority of the grandparents aged 62-85 years in the 2002 replication sample indicated that they had provided neither financial nor instrumental support to grandchildren, and that they had not received any such support from them. Most of those who did provide support to their grandchildren only made financial transfers-without receiving anything in return. The mutual exchange of financial and instrumental support between grandparents and grandchildren was practically nonexistent - there were only io cases of exchanged support. Support exchange was slightly more common between parents and their adult children. Nearly one-fifth of the grandparents aged $62-85$ years exchanged financial and instrumental transfers with their children, but the provision of only financial support by the older generation, without receiving anything in return, was again predominant. On the other hand, about one-quarter received instrumental assistance from their children without giving any support in return. Genuine dyadic exchange was far less likely than the summary statistics suggest.

\section{Financial transfers to children and grandchildren}

A significant shift in the proportion of grandparents making financial transfers toward grandchildren, seemingly at the expense of children, occurred between 1996 and 2002. To gain a better understanding of the change, we now compare financial transfers towards grandchildren and children more closely, first, by examining the estimated values of the financial transfers. The respondents were asked to indicate the amount of money that they had given to others over the previous 12 months. They were presented with categories of value, ranging from 'less than $€_{250}$ ' to

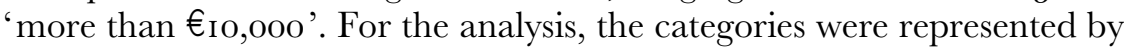
the mid-class values, e.g. $25^{0}-500$ was represented by 375 . The principal finding is that older people provided far more financial support to their children than to their grandchildren. In 2002, each grandparent aged $62-85$ years who provided any financial support gave on average $€_{I, 250}$ to her or his grandchildren, but nearly three times more $\left(€_{3,500}\right)$ to his or her children. It is however notable that overall financial support to the younger generations had decreased since i996. For each of the four agegroups, grandparents in 1996 on average provided a larger sum to both 
their children and their grandchildren than their counterparts in 2002. Generally, grandfathers transferred a larger amount than grandmothers, which reflects their higher pensions and savings.

\section{Longitudinal perspectives on financial transfers}

The main finding of the analyses reported thus far is that German grandparents aged $62-85$ years were more likely to support their grandchildren in 2002 than six years earlier. The increasing propensity to support grandchildren was particularly pronounced in the younger age groups, whereas a reduction in the propensity to support children was most evident in the oldest age group. It is important to note that all the findings so far discussed make statements about groups of older people and do not allow conclusions to be drawn about individual behaviour. It may well be that those who gave support to grandchildren in 2002 were not the same as those who did not support their children. To examine the combinations of support further, we first explore if grandparents gave money exclusively to their children, exclusively to their grandchildren, or to both generations.

It is not possible to observe changes of individual behaviour over time from two independent samples, such as the 1996 baseline and 2002 replication samples. The support propensities were therefore re-estimated from the longitudinal sample of the German Ageing Survey. These estimates corroborated the finding that the proportion of grandparents that provided financial support exclusively to their grandchildren rose from one-fifth in I996 (when aged 62-85 years) to one-third in 2002 (when aged 68-9I years). Over the same period, the share of those who gave money only to their children fell from more than 60 per cent to just over 40 per cent. While the comparison of the 2002 replication and the 1996 baseline samples suggested cross-cohort changes, any cohort effects would have been confounded by age effects in the longitudinal analysis. The sample respondents were aged 62-85 years in 1996; six years later, when they were 68-9I years old, they had more grandchildren, which would at least partly explain the higher percentage making financial transfers to grandchildren. Furthermore, the grandchildren were now older and their need for financial assistance would have been greater. Table 2 presents a more detailed picture of the changes between 1996 and 2002. The combination of four variants of support (financial support to neither children nor grandchildren, to children only, to grandchildren only, to both children and grandchildren) in the first and second wave implied $4^{2}$ or 16 possible combinations. 
T A B L E 2. Changing patterns of financial support of grandchildren and children, Germany 1996 and 2002

\begin{tabular}{|c|c|c|c|c|}
\hline $\begin{array}{l}\text { Support given } \\
\text { in } 1996\end{array}$ & $\begin{array}{l}\text { Support given } \\
\text { in } 2002\end{array}$ & $\begin{array}{c}\text { Number } \\
\text { (not weighted) }\end{array}$ & $\begin{array}{l}\text { Per cent } \\
\text { (weighted) }\end{array}$ & $\begin{array}{l}\text { Per cent } \\
\text { (weighted) }\end{array}$ \\
\hline To children only & To grandchildren only & IO & $3 \cdot 9$ & $2 . I$ \\
\hline To children only & To both & I5 & 6.5 & $3 \cdot 4$ \\
\hline To children only & No support & $4^{0}$ & $2 \mathrm{I} .9$ & II. 6 \\
\hline To children only & To children only & 20 & I0.4 & $5 \cdot 5$ \\
\hline To grandchildren only & No support & I6 & IO.I & $5 \cdot 4$ \\
\hline No support & To children only & $3^{0}$ & $\mathrm{I} 3 \cdot 3$ & 7.1 \\
\hline No support & To grandchildren only & 27 & I2.6 & 6.7 \\
\hline $\begin{array}{l}\text { Number of cases } \\
\text { itemised above }\end{array}$ & & I $5^{8}$ & 78.7 & $4 \mathrm{I} .8$ \\
\hline $\begin{array}{l}\text { Nine other combinations } \\
\text { involving support }\end{array}$ & & $5^{2}$ & $2 \mathrm{I} \cdot 3$ & II.3 \\
\hline Subtotal & & 210 & IOO.O & \\
\hline No support & No support & I6I & & $4^{6.9}$ \\
\hline Total & & $37 \mathrm{I}$ & & IOO.O \\
\hline
\end{tabular}

Source: German Ageing Survey, panel sample 1996 and 2002 with all respondents aged 62-85 years in 1996 who were grandparents $(\mathrm{N}=37 \mathrm{I})$ and who gave money to children/grandchildren in I996 or $2002(\mathrm{~N}=2 \mathrm{IO})$.

While the results for I996 and 2002 suggested that German grandparents shifted a considerable proportion of their financial support away from their children and towards their grandchildren, the longitudinal analysis did not confirm this change. Only Io grandparents in the selected age group made financial transfers exclusively to their children in 1996 and then in 2002 exclusively to their grandchildren. Similarly, only a low percentage (6.5) of those who gave money only to their children in 1996 gave to both children and grandchildren in 2002. On the other hand, a larger percentage (I2.6) of those who provided no financial support in I996 six years later gave money to their grandchildren but not to their children. Most importantly, however, more than one-fifth of those who had given money to their children in 1996 did not make any financial transfers to children or grandchildren in 2002. All in all, the reduction in financial support of children was more pronounced than that of grandchildren. An age effect seems to be the most likely explanation, given that in 2002 the youngest respondents were 68 years old, and the oldest were well into the 'fourth age'.

\section{Conclusions: a changing balance of intergenerational support?}

The objective of this paper was to look at change and continuity in the patterns of supportive transfers between grandparents and grandchildren 
in Germany between 1996 and 2002. Whereas most research on the functional aspect of the grandparent-grandchild relationship has focused on child-care issues, this paper has concentrated on two other support types that are at the heart of support exchanges between parents and children: financial transfers and instrumental assistance. Two theoretical constructs led to the hypotheses that have guided this research: the intergenerational solidarity hypothesis of Bengtson and Roberts (I99I), and the intergenerational stake hypothesis of Giarrusso, Stallings and Bengtson (1995). Two additional hypotheses that take into account the effect of age on supportive behaviour were proposed: (a) that the extent of support varies with age, and (b) that the intergenerational stake hypothesis does not apply to supportive relations between the younger generations and very old grandparents, because of their high need for instrumental assistance.

To summarise the findings, financial and instrumental support are first considered separately. In 2002, nearly one-fifth of 62-85 year-old grandparents provided financial support to their grandchildren, and onequarter to their children. A remarkable shift was found in the likelihood of financial transfers between 1996 and 2002, away from adult children and towards grandchildren. From a comparison of the 1996 baseline sample with the 2002 replication sample, it has been shown that the proportion of grandparents that reported financial transfers over the previous year to grandchildren increased by five per cent, but that to children decreased by three per cent. Analysis of the reports from the longitudinal panel in 1996 and 2002 found that an increasing share of $62-85$ year-old grandparents gave financial support solely to grandchildren, and a decreasing share gave exclusively to children. Nevertheless, adult children were still more likely to be recipients of financial transfers than grandchildren, and the value of the financial gifts to children was almost three times higher than to grandchildren. When grandparents financially supported their grandchildren, one-off transfers were the rule, and very few provided regular financial support.

The age differentiation hypothesis is that the provision and receipt of financial and instrumental transfers alter with the age of the grandparents, so the analysis was repeated controlling for the grandparents' ages. The results showed that the above-mentioned shift in intergenerational support patterns occurred for all age groups of grandparents. While a higher likelihood of financial transfers to grandchildren was found in all but the oldest cohort, only the oldest cohort reported a considerable decrease in their propensity to provide their children with financial assistance. The fourth hypothesis - the changing needs or capacity hypothesis - was particularly expected to apply to instrumental assistance for grandparents 
aged 80 or more years. The hypothesis was largely based on the idea that the oldest people need more support for reasons of frailty and multimorbidity, but also that adult grandchildren have a greater support capacity than young grandchildren, not least to provide instrumental help. In contrast to adult children, very few grandchildren reciprocated financial transfers by means of instrumental assistance in either 1996 or 2002. Thus, the 'greater needs or capacity hypothesis' is rejected for the grandparent-grandchild relationship - but there is clear evidence of its validity for the parent-child relationship.

A final comment about the mutuality of support provision is appropriate. This article has shown, in line with previous findings, that the functional dimensions of intergenerational relationships are imbalanced at the older generation's expense. In other words, the support relationship of grandparents with their grandchildren is even more imbalanced than that with their children. The $62-85$ year-old German grandparents were generally more likely to support their grandchildren and children than vice versa. This outcome confirms the overall validity of the 'intergenerational stake hypothesis', but there was one exception: the alternative 'greater needs or capacity hypothesis' applied to very old grandparents. Only for these dyads was the propensity of the younger generation to provide support (in this case instrumental assistance) greater than that of the older generation to provide financial support. The grandparent-grandchild relationship is not therefore characterised by mutual exchange. The substantial 'downwards' financial transfers were not matched by reciprocal 'upwards' instrumental support - not even toward the 'oldest old'. Overall therefore, whereas supportive behaviour in the parent-child relationship is governed by the principle of intergenerational (functional) solidarity, the grandparent-grandchild relationship is guided by an 'intergenerational stake' and not by intergenerational (functional) solidarity.

What broader conclusions can be drawn from these findings, particularly in the light of anticipated demographic and family changes? The spread of the 'beanpole family' (Bengtson, Rosenthal and Burton I990) will result in fewer grandchildren, but on the other hand, rising average life expectancies will increase the average number of years that each person spends as both a grandchild and a grandparent. Thus, the prospect of four healthy grandparents - in step-families possibly even more competing for the attention of just one grandchild is no longer fanciful. A shift in the destination of financial transfers towards grandchildren may signal a changing attitude towards grandchildren, and perhaps they will be valued more highly. Future research on change and continuity in intergenerational norms, values and attitudes should monitor and test this claim. 
The analysis reported in this paper has several limitations, not least that it has been confined to financial and instrumental support. The incorporation of other support dimensions, such as emotional support, cognitive support and child-care, would give a more complete understanding of the grandparent-grandchild relationship. A major shortcoming arose from the nature of the data. All national ageing surveys face the dilemma of wanting to collect as much information as possible but being constrained in doing so. There is an obvious trade-off between maximising the data collected and restraining the time spent on the task. Single-purpose surveys of the grandparent-grandchild relationship would provide fuller and better information for the analysis of mutual support relations. Ideally, such surveys should incorporate all aspects of the grandparent-grandchild dyad and the grandparent-child-grandchild triad.

\section{Acknowledgements}

I gratefully acknowledge the funding of the German Ageing Survey by the Ministry for Family Affairs, Senior Citizens, Women and Youth of the German Federal Government. Moreover, I would like to thank Sarah Harper and George Leeson for comments on an early version of this paper. I am grateful for very helpful comments by the participants of the RTN Network 'Grandparenthood and Intergenerational Relationships in Aging European Populations' workshop in Oxford in April 2005, at which I presented an earlier version of this paper. Finally, I thank two anonymous referees of this paper for their extremely valuable comments, and express gratitude to Sue Marcus for her editorial support.

\section{NOTES}

I The survey was commissioned by the German Federal Ministry for Families, Senior Citizens, Women, and Youth. Additional details are given in the Acknowledgements, in Hoff et al. (2003) and in Engstler and Wurm (2006).

2 A preliminary overview of differences between the older non-German and German population can be found in Baykara-Krumme and Hoff (2006).

3 This graphic device was first used by the Research Group on Aging and the Life Course (FALL) at the Free University of Berlin to visualise the patterns of intergenerational transfers (see Kohli et al. 2000).

\section{References}

Antonucci, T. C. I99o. Social supports and social relationships. In Binstock, R. H. and George, L. K. (eds), Handbook of Aging and the Social Sciences. Academic Press, New York, $205^{-26 .}$

Atkinson, M. P., Kivett, V. R. and Campbell, R. T. i986. Intergenerational solidarity: an examination of a theoretical model. Fournal of Gerontology, 4I , 6, 408-16. 
Attias-Donfut, C. 2003. Family transfers and cultural transmissions between three generations in France. In Bengtson, V. L. and Lowenstein, A. (eds), Global Ageing and Challenges to Families. De Gruyter, Hawthorne, New York, 214-52.

Bass, S. A. and Caro, F. G. I996. The economic value of grandparent assistance. Generations, 20, I, 29-33.

Bawin-Legros, B. and Stassen, J.-F. 2002. Intergenerational solidarity: between the family and the state. Current Sociology, 5o, 2, 243-62.

Baydar, N. and Brooks-Gunn, J. 1998. Profiles of grandmothers who help care for their grandchildren in the United States. Family Relations, 47, 4, 385-93.

Baykara-Krumme, H. and Hoff, A. 2006. Die Lebenssituation älterer Ausländerinnen und Ausländer in Deutschland [The circumstances of older foreign nationals in Germany]. In Tesch-Römer, C., Engstler, H. and Wurm, S. (eds), Altwerden in Deutschland [Growing Old in Germany]. VS Verlag für Sozialwissenschaften, Wiesbaden, Germany, 447-518.

Bengtson, V. L. 1975. Generation and family effects in value socialization. American Sociological Review, 40, 3, 358-7I.

Bengtson, V. L. 200I. Beyond the nuclear family: the increasing importance of multigenerational relationships in American society. Fournal of Marriage and the Family, 63, I, I-I6.

Bengtson, V. L., Olander, E. B. and Haddad, A. A. I976. The 'generation gap' and aging family members: toward a conceptual model. In Gubrium, J. F. (ed.), Time, Roles, and Self in Old Age. Human Sciences Press, New York, 237-63.

Bengtson, V. L. and Roberts, R. E. L. I99I. Intergenerational solidarity in aging families: an example of formal theory construction. Fournal of Marriage and the Family, 53, 4, 856-70.

Bengtson, V. L., Rosenthal, C. and Burton, L. I99o. Families and aging: diversity and heterogeneity. In Binstock, R. H. and George, L. K. (eds), Handbook of Aging and the Social Sciences. Academic, New York, 263-87.

Bengtson, V. L. and Schrader, S. S. I982. Parent-child relations. In Mangen, D. and Peterson, W. (eds), Handbook of Research Instruments in Social Gerontology. Volume 2, University of Minnesota Press, Minneapolis, Minnesota, II5-85.

Caldwell, C. H., Antonucci, T. C. and Jackson, J. S. I998. Supportive/conflictual family relations and depressive symptomatology: teenage mother and grandmother perspectives. Family Relations, 47, 4, 395-402.

Cherlin, A. and Furstenberg, F. I986. The New American Grandparent. Harvard University Press, Cambridge, Massachusetts.

Cooney, T. M. and Smith, L. A. 1996. Young adults' relations with grandparents following recent parental divorce. Fournal of Gerontology: Social Sciences, 5 I B, I, S9I-5.

Crosnoe, R. and Elder, Jr., G. H. 2002. Life course transitions, the generational stake, and grandparent-grandchild relationships. Fournal of Marriage and the Family, 64, 4, 1089-96.

Dimmock, B., Bornat, J., Pearce, S. and Jones, D. 2004. Intergenerational relationships among UK stepfamilies. In Harper, S. (ed.), Families in Ageing Societies. Oxford University Press, Oxford, 82-94.

Dittmann-Kohli, F., Kohli, M., Künemund, H., Motel, A., Steinleitner, C. and Westerhof, G.J. I997. Lebenszusammenhänge, Selbst- und Lebenskonzeptionen-Erhebungsdesign und Instrumente des Alters-Survey [Life Associations, Self and Life Conceptions: Methodological Design of the German Ageing Survey]. Freie Universität Berlin, Forschungsgruppe Altern und Lebenslauf, Berlin. Available online at http://www.fall-berlin.de/ [Accessed 23 February 2007].

Engstler, H. and Wurm, S. 20o6. Datengrundlagen und Methodik [Database and methodology]. In Tesch-Römer, C., Engstler, H. and Wurm, S. (eds), Altwerden in Deutschland [Growing Old in Germany]. VS Verlag für Sozialwissenschaften, Wiesbaden, Germany, $47^{-84}$. 
Fabian, T. I994. Großeltern als Helfer in familialen Krisen [Grandparents as helpers in family crises]. Neue Praxis, 24, 6, 384-96.

Ferguson, N. 2004. Grandparenting in Divorced Families. Policy Press, Bristol, Avon.

Fthenakis, W. E. I998. Intergenerative familiale Beziehungen nach Scheidung und Wiederheirat aus der Sicht der Großeltern Intergenerative family relations after divorce and remarriage from the perspective of the grandparents]. Zeitschrift fïr Soziologie der Erziehung und Sozialisation, I8, 2, I52-67.

Gauthier, A. 2002. The role of grandparents. Current Sociology, 5o, 2, 295-307.

Giarrusso, R., Feng, D., Silverstein, M. and Bengtson, V. L. 200ı. Grandparent-adult grandchild affection and consensus. Fournal of Family Issues, 22, 5, 456-77.

Giarrusso, R., Stallings, M. and Bengtson, V. L. 1995. The 'intergenerational stake' hypothesis revisited: parent-child differences in perceptions of relationships 20 years later. In Bengtson, V. L., Schaie, K. W. and Burton, L. M. (eds), Intergenerational Issues in Aging: Effects of Societal Change. Springer Publishing Company, New York, 227-63.

Hareven, T. K. 200ı. Historical Perspectives on Aging and Family Relations. In Binstock, R. H. and George, L. K. (eds), Handbook of Aging and the Social Sciences. Academic, San Diego, California, I4 $\mathrm{I}^{-} 59$.

Harper, S. 2005. Understanding grandparenthood. In Johnson, M. (ed.), Handbook of Age and Ageing. Cambridge University Press, Cambridge, 422-8.

Harper, S., Smith, T., Lechtman, Z., Ruicheva, I. and Zeilig, H. 2004. Grandmothercare in Lone Parent Families. Oxford Institute of Ageing, Oxford.

Harwood, J. 200I. Comparing grandchildren's and grandparents stake in their relationship. International Fournal of Aging and Human Development, 53, 3, I95-210.

Hodgson, L. G. 1998. Grandparents and older grandchildren. In Szinovacz, M. E. (ed.), Handbook on Grandparenthood. Greenwood, Westport, Connecticut, I7 I-83.

Hoff, A. 2006a. Intergenerationale Familienbeziehungen im Wandel [Changing intergenerational family relations]. In Tesch-Römer, C., Engstler, H. and Wurm, S. (eds), Altwerden in Deutschland [Growing Old in Germany]. VS Verlag für Sozialwissenschaften, Wiesbaden, Germany, 23 ${ }^{\mathrm{I}-87}$.

Hoff, A. 2006 b. Lone Mothers Between the Welfare State and Informal Support: A Cross-national Comparison of Germany and the UK. Edwin Mellen, Lewiston, New York.

Hoff, A. 2007. Functional Solidarity Between Grandparents and Grandchildren in Germany. Working Paper 307, Oxford Institute of Ageing, University of Oxford, Oxford.

Hoff, A. and Tesch-Römer, C. 2007. Family relations and aging: substantial changes since the middle of the last century? In Wahl, H.-W., Tesch-Römer, C. and Hoff, A. (eds), New Dynamics in Old Age: Individual, Environmental and Societal Perspectives. Baywood, Amityville, New York, 65-84.

Hoff, A., Tesch-Römer, C., Wurm, S. and Engstler, H. 2003. 'Die zweite Lebenshälfte' - der Alters-survey zwischen gerontologischer Längsschnittanalyse und Alterssozialberichterstattung im Längsschnitt ['The second half of life': the German Ageing Survey between gerontological longitudinal analysis and longitudinal old-age social reporting]. In Karl, F. (ed.), Sozial- und verhaltenswissenschaftliche Gerontologie [Social and Behavioural Science Gerontology]. Juventa, Weinheim, Germany, I85-204.

Kivett, V. R. 1985. Grandfathers and grandchildren: patterns of association, helping, and psychological closeness. Family Relations, 34, 4, 565-7i.

Kohli, M., Künemund, H., Motel, A. and Szydlik, M. 200o. Generationenbeziehungen [Intergenerational relations]. In Kohli, M. and Künemund, H. (eds), Die zweite Lebenshälfte [The Second Half of Life]. Leske and Budrich, Opladen, Germany, I76-2 I I.

Krappmann, L. 1997. Brauchen junge Menschen alte Menschen? [Do younger people need older people?] In Krappmann, L. and Lepenies, A. (ed.), Alt und Jung. Spannung und Solidarität zwischen den Generationen [The Old and the Young: Intergenerational Tensions and Solidarity]. Campus, Frankfurt-on-Main, 185-204. 
Kronebusch, K. and Schlesinger, M. 1994. Intergenerational transfers. In Bengtson, V. L. and Harootyan, R. A. (eds), Intergenerational Linkages: Hidden Connections in American Society. Springer Publishing Company, New York, I I2-5I.

Künemund, H., Motel-Klingebiel, A. and Kohli, M. 2005. Do intergenerational transfers from older parents increase social inequality among their middle-aged children? Evidence from the German Ageing Survey. Journal of Gerontology: Social Sciences, 6oB, I, $\mathrm{S}_{30}-6$.

Langer, N. 1990. Grandparents and adult grandchildren: what do they do for one another? International Fournal of Aging and Human Development, 31, 2, IOI-IO.

Lange, A. and Lauterbach, W. 1997. Wie nahe wohnen Enkel bei ihren Großeltern? Aspekte der Mehrgenerationenfamilie heute [How Close do Grandchildren and Grandparents Live? Aspects of the Multigenerational Familiees Today]. Universität Konstanz, Constance, Germany.

Lange, A. and Lauterbach, W. 1998. Aufwachsen mit oder ohne Großeltern? Die gesellschaftliche Relevanz multilokaler Mehrgenerationenfamilien [Growing up with or without grandparents? The societal relevance of multilocal multigenerational families]. Zeitschrift für Soziologie der Erziehung und Sozialisation. 1 8, 3, 227-49.

Lauterbach, W. I995 $a$. Die gemeinsame Lebenszeit von Familiengenerationen [The joint life-time of family generations]. Zeitschrift für Soziologie, 24, I, 23-43.

Lauterbach, W. I995 b. Enkel und Großeltern: Generationenlinien, Altersübergänge und gemeinsame Lebenszeit [Grandchildren and grandparents: generational lineage, oldage transitions and joint lifetimes]. In Sahner, H. and Schwendtner, S. (eds), Gesellschaften im Umbruch [Societies in Transition]. Leske and Budrich, Opladen, Germany, 745-53.

Lauterbach, W. 2002. Großelternschaft und Mehrgenerationenfamilien - soziale Realität oder demographischer Mythos? [Grandparenthood and multigenerational families: social reality or demographic myth?] Zeitschrift für Gerontologie und Geriatrie, 35, 6, 540-55.

Lauterbach, W. and Klein, T. I997. Altern im Generationenzusammenhang [Ageing in intergenerational relationships]. In Mansel, J., Rosenthal, G. and Tölke, A. (eds), Generationenbeziehungen, Austausch und Tradierung [Intergenerational Relations, Exchange and Tradition]. Westdeutscher Verlag, Opladen, Germany, ı09-20.

Lüscher, K. and Liegle, L. 2003. Generationenbeziehungen in Familie und Gesellschaft [Intergenerational Relations in Family and Society]. Universitätsverlag Konstanz, Constance, Germany.

Marbach, J. H. I994. Tauschbeziehungen zwischen Generationen-Kommunikation, Dienstleistung und finanzielle Unterstützung in Dreigenerationenfamilien [Intergenerational exchange relations: communication, service provision and financial support in three-generation families]. In Bien, W. (ed.), Eigeninteresse oder Solidarität. Beziehungen in modernen Mehrgenerationenfamilien [Self-interest or Solidarity: Relationships in Modern Multigenerational Families]. Leske and Budrich, Opladen, Germany, ı63-96.

Minkler, M., Fuller-Thomson, E., Miller, D. and Driver, D. 2000. Grandparent caregiving and depression. In Hayslip, Jr, B. and Goldberg-Glen, R. (eds), Grandparents Raising Grandchildren: Theoretical, Empirical, and Clinical Perspectives. Springer Publishing Company, New York, 207-20.

Motel-Klingebiel, A. 200o. Alter und Generationenvertrag im Wandel des Sozialstaats [Old Age, the Intergenerational Contract and the Changing Social Welfare State]. Weißensee, Berlin.

Pruchno, R. 1999. Raising grandchildren: the experience of black and white grandmothers. The Gerontologist, 39, 2, 209-2I.

Roberto, K. A. and Stroes, J. I995. Grandchildren and grandparents: roles, influences, and relationships. In Hendricks, J. (ed.), The Ties of Later Life. Baywood, Amityville, New York, $\mathrm{I}_{4} \mathrm{I}-53$.

Roberts, R. E. L. and Bengtson, V. L. I99o. Is intergenerational solidarity a unidimensional construct? A second test of a formal model. Fournal of Gerontology: Social Sciences, 45, I, SI2-20. 
Ross, N., Hill, M., Sweeting, H. and Cunningham-Burley, S. 2002. Grandparents and Teen Grandchildren: Exploring Intergenerational Relationships. Centre for Research on Families and Relationships, University of Edinburgh, Edinburgh.

Silverstein, M. 2006. Intergenerational family transfers in social context. In Binstock, R. H. and George, L. K. (ed.), Handbook of Aging and the Social Sciences. Sixth edition, Academic, Burlington, Massachusetts, I65-80.

Silverstein, M. and Long, J. D. I998. Trajectories of grandparents' perceived solidarity with adult grandchildren: a growth curve analysis over 23 years. Fournal of Marriage and the Family, 6o, 4, 912-23.

Silverstein, M. and Marenco, A. 200I. How Americans enact the grandparent role across the family life course. Fournal of Family Issues, 22, 5, 493-522.

Silverstein, M., Giarusso, R. and Bengtson, V. L. I998. Intergenerational solidarity and the grandparent role. In Szinovacz, M. E. (ed.), Handbook on Grandparenthood. Greenwood, Westport, Connecticut, I44-58.

Sommer-Himmel, R. 200ı. Großeltern heute. Betreuen, erziehen, verwöhnen. [Grandparents Today: To Look After, To Bring Up, To Spoil]. Universität Bielefeld, Bielefeld, Germany.

Szinovacz, M. E. I998. Grandparenting research: past, present, and future. In Szinovacz, M. E. (ed.), Handbook on Grandparenthood. Greenwood, Westport, Connecticut, I-22.

Szydlik, M. 200o. Lebenslange Solidarität? Generationenbeziehungen zwischen erwachsenen Kindern und ihren Eltern [Life-long Solidarity? Intergenerational Relations Between Adult Children and Their Parents]. Leske and Budrich, Opladen, Germany.

Tesch-Römer, C., Wurm, S., Hoff, A. and Engstler, H. 2002. Die zweite Welle des Alterssurveys. Erhebungsdesign und Instrumente [The Second Wave of the German Ageing Survey. Methodological Design and Instruments]. Deutsches Zentrum für Altersfragen, Berlin. Available online at http://www.dza.de/download/Alterssurvey_Instrumente.pdf [Accessed 23 February 2007].

Uhlenberg, P. 2005. Historical forces shaping grandparent-grandchild relationships: demography and beyond. In Silverstein, M. (ed.), Intergenerational Relations Across Time and Place. Annual Review of Gerontology and Geriatrics. Springer Publishing Company, New York, 77-97.

Von Hentig, H. 1946. The sociological function of the grandmother. Social Forces, 24, 4, 389-92.

Wilk, N. I993. Großeltern und Enkelkinder [Grandparents and grandchildren]. In Lüscher, K. and Schultheis, F. (eds), Generationenbeziehungen in 'postmodernen Gesellschaften' [Intergenerational Relations in 'Post-modern Societies']. Universitätsverlag Konstanz (UVK), Konstanz, Germany, 03-I4.

Address for correspondence:

Accepted for publication 28 February 2007

Andreas Hoff, Oxford Institute of Ageing, University of Oxford, Manor Road, Oxford OXI 3 UQ, UK.

Email: andreas.hoff@ageing.ox.ac.uk 